\title{
LANSKAP HUNIAN KALA PLESTOSEN - AWAL HOLOSEN KAWASAN GUNUNG SEWU: PENGARUH LINGKUNGAN ALAM DALAM BERTAHAN HIDUP
}

\author{
Settlement Landscapes of The Pleistocene - The Early Holosen of The Gunung Sewu \\ Area: The Influence of The Natural Environment in Survival
}

\author{
Indah Asikin Nurani \\ Hari Wibowo \\ Balai Arkeologi Provinsi D.I.Yogyakarta \\ Jalan Gedongkuning 174, Kotagede, Yogyakarta \\ E-mail: anikardani@gmail.com
}

\begin{abstract}
The area of Gunung Sewu shows the existence of several prehistoric occupation patterns in the Pleistocene to the Early Holocene. The patterns of human occupation in this area are not only characterized by their dwellings, but also by other activities. The prehistoric inhabitants of Gunung Sewu were able to extract, and then modify natural resources to meet their needs. Their technology is heavily influenced by the availability of surrounding natural resources, especially raw materials (stones, shells, and bones). Therefore, the relationship between humans and the raw material resources location is also an important indication of a human activity location. This paper will reveal the contribution of natural changes to the development of paleolithic technology (Pleistocene) and the Mesolithic - neolithic technologies (Holocene). The relationship between occupation, technology, and the natural environment will be reviewed through an approach to archaeological landscapes and setting systems. The conclusion that can be drawn is that the landform, their availability of raw materials, and their food sources are indicating a spatial pattern in subsistence strategies.
\end{abstract}

Keywords: archaeological landscape, Oyo watershed, Baksoko watershed, Pleistocene; Holocene

\begin{abstract}
Abstrak
Kawasan Gunung Sewu menunjukkan adanya pola okupasi tertentu pada kurun waktu sejak Kala Plestosen hingga Awal Holosen. Pola okupasi manusia di kawasan Gunung Sewu baik hunian tempat tinggal maupun sebaran lokasi beraktivitas lainnya memberikan petunjuk utama adanya aktivitas manusia. Pengembangan teknologi sangat dipengaruhi ketersediaan sumber daya alam sekitarnya, terutama bahan baku (batu, cangkang kerang, tulang). Oleh karena itu, hubungan antara manusia dengan lokasi keberadaan sumber daya bahan baku menjadi petunjuk yang penting sebagai tempat beraktivitas manusia. Tulisan ini akan mengungkap adanya perubahan alam yang signifikan antara alam kala Plestosen dengan mengembangkan teknologi paleolitik dengan alam Kala Holosen yang mengembangkan teknologi mesolitik - neolitik. Hubungan antara okupasi, teknologi, dan lingkungan alam akan dikaji melalui pendekatan lanskap arkeologi dan sistem setting. Kesimpulan yang dapat ditarik adalah bentuk lahan dengan ketersediaan bahan baku dan sumber makanan menunjukkan adanya pola keruangan manusia dalam mempertahankan hidup.
\end{abstract}

Kata kunci: arkeologi lanskap; DAS Oyo, DAS Baksoko, Plestosen, Holosen 


\section{PENDAHULUAN}

Kawasan Gunung Sewu, oleh sebagian arkeolog disebut sebagai "metropolitan prasejarah" atau "ibu kota" prasejarah (H. T. Simanjuntak et al., 2004) karena kawasan Gunung Sewu tersimpan jejak budaya yang sangat potensial. Berbagai tinggalan sejak kala Plestosen dengan budaya paleolitik sampai dengan kala Holosen tinggalan paleometalik lengkap ditemukan melimpah dan bervariasi di kawasan Gunung Sewu. Pola hidup kala Plestosen dengan pengembangan teknologi paleolitik jejak budayanya (artefak) tersebar di sungai-sungai purba seperti Kali Oyo di Gunungkidul dan Kali Baksoko di Pacitan. Selanjutnya pada kala akhir Plestosen - awal Holosen, pola hidup beralih dari hunian di tempat terbuka ke hunian di gua atau ceruk dengan pengembangan teknologi mesolitik. Selain itu, pola hidup kedua kala tersebut memberikan gambaran terjadinya perubahan alam dan pola hidup dengan manusia pendukungnya yang berbeda genus pula. Perubahan alam antara kala Plestosen dengan kala Holosen sangat signifikan perubahannya.

Alam kala Plestosen masih terjadi zaman glasial-interglasial yang sangat mempengaruhi makhluk hidup dalam mempertahankan hidupnya. Arus migrasi fauna pun terjadi, akibat peralihan alam dari darat menjadi lautan dan sebaliknya. Hal tersebut pun sangat berpengaruh pada pola hidup manusia pada kala Plestosen, yaitu Homo erectus yang masih sangat dipengaruhi ketersediaan alam sekitarnya (fauna dan flora) dalam mempertahankan hidupnya. Manusia purba (Homo erectus) yang hidup kala Plestosen, dalam terminologi mata pencahariannya dikelompokkan hidup berburu dan mengumpulkan makanan tingkat sederhana (Soejono, 1976). Manusia waktu itu hidup secara nomaden di daerah-daerah yang subur jauh dari segala ancaman baik binatang buas maupun bencana alam, dekat dengan sumber makanan, air, dan tersedia bahan baku untuk pembuatan peralatan sehari-hari. Pembuatan peralatan sehari-hari mereka kembangkan dengan teknologi paleolitik antara lain berupa kapak perimbas, kapak penetak, dan kapak genggam. Berbeda halnya kondisi alam kala Holosen yang didukung oleh manusia modern yaitu Homo sapiens. Mereka mulai menempati gua atau ceruk untuk bertempat tinggal dan bertahan hidup dengan mengembangkan teknologi mesolitik untuk pembuatan peralatan sehari-hari. Teknologi mesolitik merupakan teknologi yang lebih maju dibandingkan dengan teknologi paleolitik, yaitu dengan adanya pangkasan sekunder setelah terlepas dari induk batu. Pangkasan sekunder dimaksudkan untuk mempertajam alat dengan membuat retus (Crabtree, 1972).

Berdasarkan hal tersebut, menarik untuk dikaji lebih lanjut perubahan kedua kala tersebut baik alam, pola hidup, dan manusia pendukungnya maupun jejak tinggalan budayanya. Tulisan ini bermaksud menjabarkan bagaimana pola adaptasi manusia kala itu yang masih sangat mengandalkan lingkungan dan potensi alam sekitarnya. Kawasan Gunung Sewu dipilih untuk menjelaskan perubahan alam dan budaya karena sangat representatif mengingat kawasan ini merupakan "metropolitan prasejarah". Untuk menjawab permasalahan tersebut, digunakan pendekatan arkeologi lanskap dan sistem setting. 
Arkeologi lanskap sesungguhnya merupakan konsep yang cukup luas dan kadang diberi pemaknaan yang beragam. Crumley dan Marquardt (1990) menyatakan, dalam kajian arkeologi, lanskap adalah manifestasi ruang yang menunjukkan relasi antara manusia dan lingkungannya. Lanskap budaya bukan semata-mata lingkungan fisik tetapi juga kerangka kognisi manusia yang sangat menentukan cara-cara manusia berinteraksi dengan lingkungan alamnya. Oleh karena itu, lanskap sekaligus menjadi peta pemikiran manusia tentang lingkungan di sekitarnya, baik yang dapat dialaminya secara langsung maupun yang dibayangkan. Berdasarkan hal tersebut, maka lanskap adalah suatu konstruksi pengetahuan tentang keadaan lingkungan. Konstruksi tersebut, menjadi dasar manusia mampu mengambil keputusan-keputusan untuk mendatangi atau menghindari suatu lokasi atau tempat, memanfaatkan atau tidak mengusik tempat itu, menjadikannya sakral atau profan, dan meninggalkannya atau menetapinya (Tanudirjo, 2017). Suatu cara bagaimana manusia memaknai dirinya dan dunianya melalui hubungannya dengan alam yang juga mempengaruhi peran sosial terkait hubungan dengan dunia luar.

Tempat-tempat (ruang) sebagai lanskap budaya manusia baik sebagai pusat aktivitas, sementara, atau jarang disinggahi akan dikaji melalui sistem setting baik melalui jejak spasial (ruang) maupun fisik (artefak). Jelajah manusia dalam mempertahankan hidup akan tercermin "site catchment area" pada konteks hubungan antara lokasi situs dengan sumber-sumber daya yang terjangkau untuk dieksplorasi oleh manusia. Selanjutnya setelah dikaji melalui arkeologi lanskap dilakukan pengolahan data dengan analisis sistem setting baik secara ruang (horizontal) maupun waktu (vertikal). Sistem setting merupakan suatu kawasan sebagai batas wilayah dari sekelompok ruang atau setting tempat manusia melakukan kegiatannya. Sekelompok setting tersebut tersusun dalam satu sistem yang mewadahi sistem kegiatan manusia (Haryadi, 1995). Kegiatan atau aktivitas manusia masa lalu meninggalkan jejak budaya atau tanda-tanda yang teramati pada suatu tempat atau ruang tertentu. Tanda-tanda tersebut, berupa tanda fisik baik utuh maupun sebagian yang ditinggalkan. Berdasarkan pembacaan tanda-tanda ruang (spatial) dan fisik (artefaktual) dapat diketahui bagaimana kegiatan manusia yang sudah lama tidak ada lagi (Haryadi, 1995). Seluruh kajian tersebut baik arkeologi lanskap maupun sistem setting atas perubahan budaya dan alam kala Plestosen dengan budaya dan alam kala Holosen diharapkan terekonstruksi pola hidup manusia dalam mempertahankan hidupnya secara utuh.

\section{PEMBAHASAN}

\section{Lingkungan dan Fauna di Gunung Sewu Kala Plestosen-Holosen}

Kondisi lingkungan alam sekarang ini di Pulau Jawa umumnya dan Gunung Sewu khususnya, sangat berbeda dengan lingkungan alam Kala Plestosen. Gunung Sewu yang sekarang kondisinya tandus di sebagian besar daerahnya, dahulu ditumbuhi oleh berbagai macam pohon yang dapat mendukung adanya kehidupan manusia prasejarah pada masa itu. Kala Plestosen, yang berlangsung 1,8 juta tahun lalu hingga 11,8 ribu tahun lalu (Hill et al., 2011), mengalami berulang kali glasiasi-interglasiasi yang 
berpengaruh pada iklim global. Periode glasiasi merujuk pada kondisi suhu bumi yang menurun, sehingga terbentuk es di kutub bumi, muka air laut pun menurun dan datarandataran baru terbentuk di berbagai tempat. Sebaliknya, periode interglasiasi merujuk pada menghangatnya suhu bumi sehingga es mencair, muka air laut mengalami kenaikan, dan dataran-dataran terendam kembali oleh air laut. Perubahan muka air laut tersebut tidak hanya disebabkan oleh glasiasi dan interglasiasi saja, namun terjadi juga pergerakan tektonik yang dapat memicu adanya perubahan muka air laut (Bemmelen, 1949).

Jawa dan Bali pada Kala Plestosen sampai Awal Holosen permukaan laut lebih rendah daripada saat ini, sampai mencapai $150 \mathrm{~m}$ lebih rendah. Selain itu, daratan tiga kali lebih luas ketika Paparan Sunda terekspos. Terlebih ketika permukaan laut hanya $40 \mathrm{~m}$ lebih rendah daripada sekarang, yang memungkinkan antara Jawa, Kalimantan, Sumatera, dan Semenanjung Melayu merupakan suatu daratan. Bali pada kala itu masih terpisahkan dari Jawa oleh selat. Selama periode permukaan laut yang lebih rendah ini, kemungkinan curah hujan dan kelembaban lebih rendah, sehingga daerah hutan musim hujan akan lebih besar. Hal tersebut menyebabkan pertukaran spesies melalui koridor hutan musim hujan antara Asia dengan Australia sangat dimungkinkan (Whitten et al., 1996). Perpindahan manusia dan fauna, disertai dengan perubahan lingkungannya telah menuntut adanya proses adaptasi, dan akhirnya berpengaruh pada proses dan perkembangan budaya manusia (T. Simanjuntak, 2006).

\section{Perubahan Iklim Kala Plestosen-Holosen di Jawa}

Hutan hujan dataran rendah nampaknya telah menjadi dominan dalam landskap Jawa Tengah selama Kala Plestosen Bawah. Pengamatan yang dilakukan pada stratigrafis (lapisan tanah) yang mengandung fosil seperti di Bumiayu, Gemolong, dan Sangiran menunjukkan bahwa hutan hujan adalah jenis vegetasi dominan antara 2,6 - 1 juta tahun lalu. Hutan ini menutupi lahan-lahan yang muncul di belakang hutan mangrove pesisir, seringkali bersama dengan hutan rawa yang luas. Selama periode glasial yang lebih kering, hutan hujan mengalami fragmentasi dan pengurangan, menciptakan dataran yang lebih terbuka (A. Sémah \& Sémah, 2012).

Pergantian dari hutan hujan ke dataran yang lebih kering dan lebih terbuka sebenarnya hanya muncul pada awal Plestosen Bawah. Hal tersebut jelas menandai respons terhadap tren iklim. Banyak yang masih harus dipahami pulau-pulau di Asia Tenggara mengenai timbulnya kondisi lingkungan Plestosen Tengah yang sebenarnya, tetapi jelas bahwa hutan hujan mengalami fragmentasi parah, sehingga menimbulkan daerah-daerah lembab lokal di antara lanskap terbuka dengan padang rumput yang luas. Catatan lengkap tentang kondisi alam kala Plestosen Tengah di wilayah Jawa belum ada, tetapi catatan Plestosen Atas memberikan beberapa informasi. Kala Plestosen Tengah diindikasikan kondisi yang cukup kontras antara 'glasial' dan 'interglasial' yang terjadi setidaknya selama 200.000 tahun (A. Sémah \& Sémah, 2012).

Kondisi lingkungan di Jawa pada Kala Plestosen Atas diwakili oleh penelitian yang dilakukan oleh van der Kaars dan Dam di Bandung (van der Kaars \& Dam, 1995). 
Pertanggalan sekitar 126.000 hingga 107.000 B.P., hutan rawa air tawar yang luas menunjukkan kondisi yang sangat lembab, suhu lebih hangat daripada sekarang. Selanjutnya sekitar 81.000 B.P. hutan rawa air tawar digantikan oleh rawa terbuka. Tidak terdapat asplenium dari hutan montana (hutan pegunungan) di daerah Bandung pada periode dari 81.000 hingga 74.000 B.P. menunjukkan bahwa kondisi iklim montana (pegunungan) memang lebih kering. Sekitar 74.000 hingga 47.000 B.P. iklim sedikit lebih basah, yang menunjukkan bahwa musim kering sedikit berkurang daripada periode sebelumnya. Sejak 62.000 hingga 47.000 B.P., suhu lebih dingin daripada antara 74.000 hingga 62.000 B.P. Selanjutnya pada 47.000 hingga 20.000 B.P. secara signifikan terjadi kondisi iklim yang jauh lebih kering, sebanding iklim kering pada periode 81.000 hingga 74.000 B.P. Perubahan signifikan pada periode ini juga menunjukkan terjadinya Glasiasi Maksimum Terakhir (GMT), dan setelah 16.000 B.P. iklim meningkat menjadi lebih hangat (van der Kaars \& Dam, 1995).

Hutan hujan di Pulau Jawa nampaknya sangat dipengaruhi oleh perubahan iklim selama Glasiasi Maksimum Terakhir. Glasial Maksimum Terakhir adalah periode terakhir dalam sejarah bumi, ketika lapisan es mencapai jangkauan terluasnya. Perluasan lapisan es mencapai jangkauan maksimalnya sekitar 26.500 tahun yang lalu. Iklim ini ditandai dengan musim hujan tenggara yang panjang dan kering, monsun barat laut yang jauh lebih lembab, dan penurunan suhu yang signifikan yang mempengaruhi lanskap di seluruh wilayah. Peningkatan curah hujan berpengaruh juga pada penurunan suhu (Westaway, Zhao, et al., 2007). Analisis speleleothem dari Jawa Timur dan Flores yang dilakukan telah mengkonfirmasi adanya peningkatan curah hujan antara 17-16.5 ribu tahun lalu (Westaway, Zhao, et al., 2007). Hutan hujan banyak yang berubah ditutupi oleh vegetasi terbuka, sebagian besar terdiri dari padang rumput (A. Sémah \& Sémah, 2012).

Peningkatan suhu ini mencapai titik maksimumnya sekitar 8.500 BP. Pada saat itu, hutan hujan mencapai titik perkembangannya yang tertinggi. Jawa Tengah, tercatat dua fase resesi hutan, pada 4.000 BP terkait dengan pengembangan padang rumput dan pada sekitar 2.800 BP terjadi resesi hutan hujan dengan perubahan iklim. Pengaruh manusia pada vegetasi terjadi di daerah Jawa Tengah mulai sekitar 1.500 BP (A. Sémah \& Sémah, 2012).

\section{Fauna}

Perubahan iklim dari kering Kala Plestosen Atas ke basah Kala Holosen juga membawa perubahan fauna. Iklim kering, yang cenderung menciptakan lanskap terbuka, telah memungkinkan hewan besar, terutama herbivora, untuk berkembang. Iklim basah telah menciptakan lanskap yang dipadati pohon, yang cocok untuk hewan yang dapat bergerak di antara pepohonan (arboreal). Fauna-fauna Kala Plestosen di Jawa ditemukan di beberapa lapisan stratigrafi yang khas, sehingga dapat dibedakan dan biostratigrafinya dapat disusun. Biostratigrafi yang dibuat oleh von Koenigswald sampai saat ini masih dipakai untuk menyebut fauna-fauna dari Kala Plestosen, yang terdiri atas Fauna Kaliglagah, Jetis, Trinil, dan Ngandong. Penelitian mengenai fosil- 
fosil ini menunjukkan bahwa mereka adalah bagian dari fauna Sino Malaya (dari Cina Selatan) dan Siva Malaya (dari India) (Mahareni, 2002). Selama tahun 1980-an, skema biostratigrafi Jawa baru telah menggantikan biozonasi klasik untuk Jawa oleh von Koenigswald. Fauna-fauna tersebut adalah: Satir (1,5 juta tahun lalu) - Ci Saat (1,2 juta tahun lalu) - Trinil (1 juta tahun lalu) - Kedung Brubus (0,8 juta tahun lalu) - Ngandong (pertanggalan belum pasti) - Punung (periode interglasial terakhir) - Wajak (Holosen) (Bergh et al., 1996; Sondaar, 1984).

Fauna Punung dari Gunung Sewu mendapat perhatian lebih selama dua dekade terakhir ini. Himpunan fauna Punung ditemukan oleh von Koenigswald pada tahun 1930-an pada batuan breksi berwarna kuning. Tempat asli penemuan himpunan fauna ini belum dapat dipastikan hingga tahun 2003 ketika tim Indonesia - Belanda berhasil menemukannya kembali (Storm et al., 2005). Berdasarkan ditemukannya kembali lokasi fauna Punung ini, pertanggalan lamanya pun kemudian didetailkan dari periode interglasial terakhir menjadi $118 \pm 3$ ribu tahun lalu (Westaway, Morwood, et al., 2007). Fauna Punung mewakili fauna dari lingkungan hutan hujan. Sejauh ini, himpunan fauna lainnya mewakili kondisi lingkungan yang kering. Selain itu, fauna Punung tidak mengandung mamalia yang sudah punah pada masa kini, tetapi mendokumentasikan penampilan pertama di Jawa dari fauna yang sepenuhnya modern, termasuk gajah, beruang matahari, orangutan (Pongo pygmaeus), siamang dan gibbon (Hylobates), dan mungkin manusia modern (Storm et al., 2005). Kecuali spesies yang sangat tergantung pada lingkungan hutan hujan, gibbon dan orangutan, rangkaian fauna Punung ini mendominasi temuan di situs-situs Kala Holosen di Gunung Sewu (Morwood et al., 2008).

Berdasarkan temuan fragmen tulang di situs-situs Gunung Sewu dapat diamati perubahan komposisi fauna selama Plestosen hingga Awal Holosen. Perubahan komposisi fauna ini mencerminkan perubahan lingkungan dari daratan kering terbuka dengan beberapa bagian yang tertutup pepohonan pada Kala Plestosen, menjadi daerah hujan tropis pada Awal Holosen. Indikasi fauna tertua yang ditemukan dalam konteks gua hunian berasal dari Song Terus. Pada kedalaman 4-5 m ditemukan sisa fauna Rhinoceros, Tapirus, dan cervid (Semah et al., 2004). Pertanggalan Uranium series tulang dan gigi yang diduga terdeposisi secara alami ini menunjukkan usia kepurbakalaan antara 187,000 +21,000/-18,000 dan 79,000 \pm 3000 BP (T. Simanjuntak, 2004). Adapun pertanggalan terbaru tahun 2010, menunjukkan usia yang lebih tua mengindikasikan gua ini sudah mulai dihuni pada 320,000 tahun lalu (T. Simanjuntak et al., 2010).

Bukti eksplorasi sumber daya alam oleh manusia pada kala Plestosen Atas terlihat lebih jelas dari temuan fragmen tulang fauna di Gua Tabuhan. Situs ini menunjukkan temuan fauna didominasi oleh mamalia besar seperti Cervidae dan Bovidae dengan jumlah yang lebih sedikit. Selain itu ditemukan juga fauna Elephantidae, babi, dan tikus. Pertanggalan dari Gua Tabuhan menunjukkan penghunian gua mulai dari 60,000 hingga 12,000 tahun lalu (T. Simanjuntak, 2004). Pertanggalan lain, dengan C-14, menghasilkan usia hunian 45,000 BP (F. Sémah et al., 
2003). Indikasi eksplorasi alam oleh manusia juga dikuatkan dengan temuan dari Song Gupuh. Lapisan fauna tertua di situs ini mencapai usia hingga 70 ribu tahun yang lalu. Beberapa fauna besar Kala Plestosen di Song Gupuh berdasarkan jumlah temuannya dapat diurutkan sebagai berikut: kera (Macaca fascicularis), rusa (Rusa sp., Muntiacus muntjak, Tragulus javanicus), bovid (Bos sp., Bubalus sp.), babi (Sus scrofa, Suidae indet.), badak (Rhinoceros sondaicus), gajah Asia (Elephas maximus), beruang matahari (Helarctos malayanus), dan tapir (Tapirus indicus). Distribusi mereka dalam stratigrafi kotak penggalian menunjukkan dampak perubahan lingkungan, ditambah peningkatan kehadiran dan preferensi manusia. Hal tersebut dapat dicontohkan dengan temuan fauna paling awal yang diwakili di situs ini didominasi oleh beberapa spesies: rusa, babi, dan bovid yang mengindikasikan kondisi terbuka dan kering umumnya, tetapi dengan beberapa hutan tertutup seperti yang diperlukan oleh tapir untuk hidup (Morwood et al., 2008).

Pertanggalan lainnya dari Song Gupuh, antara 17 hingga 10 ribu tahun lalu, terasosiasikan dengan jumlah dan jenis fauna di situs yang meningkat secara signifikan; rusa, babi, bovid, beruang, gajah, badak, dan tapir semuanya jelas terkait dengan sisasisa rangka manusia modern. Berdasarkan fragmen tulang dan gigi fauna yang ditemukan, kera adalah fauna dengan peningkatan paling tinggi (Morwood et al., 2008). Peningkatan jumlah sisa kera ekor panjang macaca yang ditemukan juga terjadi di situs penggalian lain di Gunung Sewu, seperti Gua Braholo dan Song Keplek (T. Simanjuntak \& Prasetyo, 2002). Hal ini merupakan indikasi kuat bahwa pemburu manusia pada masa itu mulai secara selektif menargetkan monyet. Selain berburu, penemuan tulang ikan dan kerang moluska laut dan air tawar adalah bukti kegiatan penangkapan ikan dan eksplorasi biota laut (T. Simanjuntak, 2006). Temuan di Song Gupuh, menunjukkan penggunaan moluska secara sistematis dimulai sekitar 12 ribu tahun lalu, bukti perluasan basis sumber daya dan transportasi pertama dari pantai (Morwood et al., 2008).

\section{Genus Homo}

Beberapa ahli menghubungkan kepunahan Homo erectus disebabkan dengan ketidakmampuan mereka untuk beradaptasi dengan perubahan lingkungan. Diyakini bahwa antara 126.000 BP dan 81.000 BP, iklim di Jawa menjadi panas dan lembab, dan mengubah lingkungan dari landskap terbuka menjadi hutan hujan tropis. Lingkungan tersebut, diasumsikan bahwa Homo erectus tidak dapat mengeksplorasi sumber daya arboreal yang tersedia dan membutuhkan kegiatan malam hari untuk mendapatkannya (Storm, 2001). Hutan hujan ini kemudian diperkirakan menghilang sebelum 10 ribu tahun lalu karena adanya perubahan iklim menjadi lebih kering dan dingin di Jawa setelah 81 ribu tahun lalu (van der Kaars \& Dam, 1995).

Homo erectus kemungkinan mampu hidup di berbagai habitat, namun spesies ini belum diketahui telah mampu bertahan hidup di hutan hujan tropis yang terbentuk di Jawa antara 126.000 BP hingga 81.000 BP. Hanya manusia modern yang dapat bertahan hidup di hutan hujan tropis dengan menggunakan teknik berburu yang "canggih", 
seperti busur dan pipa tiup, untuk mencapai daerah tinggi di pohon dan/atau dengan mempertahankan pasokan makanan yang stabil dengan membudidayakan tanaman. Sampai saat ini belum ada bukti bahwa Homo erectus menggunakan strategi berburu dan budidaya ini (Storm et al., 2005).

Apabila Homo erectus cenderung berkeliaran di lanskap terbuka di sekitar sungai dan mata air, Homo sapiens di sisi lain, telah menggunakan gua dan ceruk untuk melakukan berbagai kegiatan. Meskipun demikian, masih ada kemungkinan bahwa di daerah-daerah tertentu, Homo sapiens juga menggunakan lanskap terbuka (Anderson, 1997). Pada 115,000 tahun lalu, manusia belum menghuni gua dan ceruk, seperti yang dibuktikan dengan temuannya yang jarang. Melalui proses adaptasi, mereka secara bertahap menggunakan gua sebagai tempat tinggal "permanen" dan berkelanjutan (T. Simanjuntak, 2006).

\section{Kronologi Hunian Kawasan Gunung Sewu}

Kronologi hunian di Kawasan Gunung Sewu Kala Plestosen sampai Kala Holosen berdasarkan penelitian-penelitian yang sudah dilakukan meliputi situs terbuka (Pacitanian) dan situs tertutup (gua-ceruk hunian) (Registrasi, 2011; H. T. Simanjuntak et al., 2004; H. T. Simanjuntak \& Widianto, 2012; T. Simanjuntak, 2004). Budaya Pacitanian yang ditemukan disepanjang Kali Baksoko, meskipun masih diperdebatkan namun mengindikasikan awal adanya penghunian di Kawasan Gunung Sewu. Pertanggalan absolut untuk periode ini belum bisa didapatkan. Sementara itu, pertanggalan relatif didapatkan dari tipologi alat batu Pacitanian di daerah aliran Kali Baksoko.

Homo erectus dan Homo sapiens kemungkinan pernah hidup berdampingan di satu kawasan yang sama. Inilah motivasi utama para cendekiawan yang banyak mencari bukti arkeologis dari periode yang penting ini, terutama di daerah karst pesisir selatan Jawa. Penelitian-penelitian yang dilakukan di Gunung Sewu berfokus untuk mencari urutan kronologis antara Akhir Plestosen hingga Awal Holosen. Sayangnya, belum ada temuan rangka yang terasosiasi langsung dengan Fase Baksoko maupun Fase Terus yang merupakan dua fase dimana Homo erectus belum punah. Pertanggalan tua 115.000 tahun lalu dari alat batu di Song Terus tidak disertai dengan temuan rangka manusia.

Temuan rangka Homo sapiens di Song Terus berasal dari lapisan di atas alat batu yang tergolong sangat tua. Pertanggalan rangka manusia temuan di Song Terus adalah 12,000 tahun yang lalu. Berdasarkan lapisan yang sama, banyak ditemukan fauna-fauna yang memberi petunjuk dalam memahami kehidupannya waktu itu. Mereka nampaknya sebagai predator harus bersaing dengan Panthera maxilla dalam memburu Macacca dan juga herbivora-herbivora lain (A.-M. Sémah et al., 2007).

\section{Potensi Arkeologi Kala Plestosen - Awal Holosen Kawasan Gunung Sewu}

G.H.R. von Koenigswald dan M.W.F. Tweedie adalah yang pertama kali menyadari potensi arkeologis kawasan Gunung Sewu, ketika mereka menemukan alatalat batu inti yang tidak jauh berbeda dengan alat-alat batu prasejarah tipe Chellean dari 
Eropa (Heekeren van, 1957). Kumpulan alat batu di Kali Baksoko, yang terkenal dengan sebutan budaya Pacitanian oleh von Koenigswald memiliki hampir semua unsur Kompleks Kapak Perimbas Penetak. Unsur-unsur yang dimaksud adalah kapak perimbas, kapak penetak, proto-kapak genggam, pahat genggam, dan serut (scrapers) dari serpihan flakes berukuran cukup besar (Heekeren van, 1957).

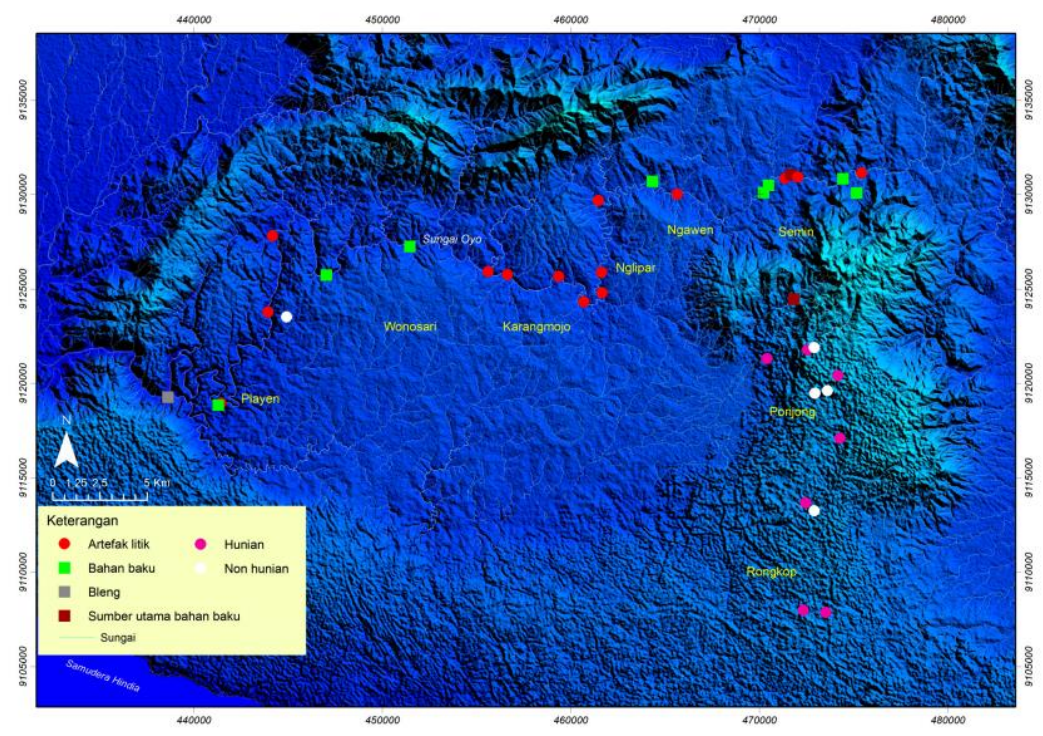

Gambar 1. Sebaran situs Plestosen - Holosen DAS Kali Oyo, Gunungkidul (sumber: Dokumen Balai Arkeologi DIY, 2016).

Sebaran temuan budaya Pacitanian di Kawasan Gunung Sewu tersebar di sepanjang Kali Oyo, Gunungkidul sampai Kali Baksoko, Pacitan. Sebaran artefak Paleolitik Pacitanian di Kali Oyo, Gunungkidul menunjukkan penempatan lokasi kegiatan yang berbeda yang ditandai masing-masing dengan keberadaan sumber utama bahan baku, bahan baku, dan produk alat-alat batu (Gambar 1). Kajian geologis menegaskan adanya perbedaan jenis batuan dengan silikaan tinggi yang berukuran bongkah sampai bom dari bagian hilir ke bagian hulu. Ketersediaan jenis bahan baku menjadi variabel yang penting dalam penempatan kegiatan. Ada keterkaitan yang cukup jelas antara perkembangan budaya dengan ketersediaan bahan baku dan produk alatnya. Berdasarkan bukti tersebut, terlihat aktivitas pembuatan alat batu Paleolitik cenderung intens "memuncak" di bagian timur Gunungkidul (Kecamatan Semin). Bagian timur dapat ditemukan sumber utama bahan baku bersama dengan temuan beberapa alat batu berteknologi Paleolitik. Sementara itu, di bagian lain kawasan ini, dari data geoarkeologis, dapat ditunjukkan bahwa okupasi manusia penghuni gua lebih banyak menempati lokasi yang berbeda, yaitu di kawasan karst zona di selatan DAS Kali Oyo.

Selanjutnya berdasarkan hasil penelitian di Kali Baksoko (Pacitan), jejak budaya Paleolitik tersebar baik artefak maupun bahan baku di daerah hulu Kali Baksoko yang terhubung dengan hulu Kali Oyo. Dengan demikian, dapat disimpulkan bahwa okupasi dan kegiataan manusia pendukung teknologi Paleolitik memang lebih memusat di kedua hulu sungai tersebut, baik Kali Oyo maupun Kali Baksoko. Adapun jejak budaya hunian gua di DAS Kali Baksoko berada di bagian barat-selatan hilir Kali Baksoko (Gambar 
2). Berdasarkan data tersebut dapat diinterpretasikan perubahan alam dari kala Plestosen ke alam kala Holosen dihadapi dengan perubahan lokasi hunian manusia ke arah perbukitan, tidak di sekitar sungai lagi. Selain itu, karena ketersediaan fauna buruan manusia yang berubah juga lebih kecil, maka peralatan sehari-hari pun juga menyesuaikan lebih kecil dengan teknologi mesolitik - neolitik.

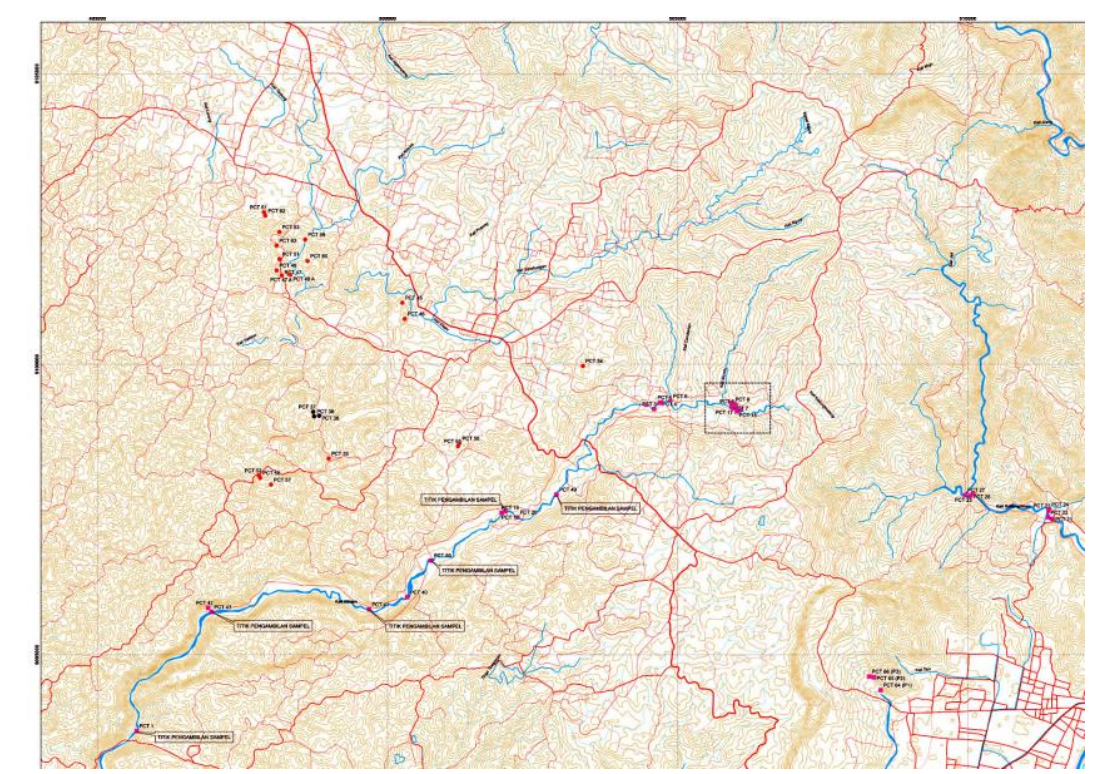

Gambar 2. Sebaran situs Plestosen - Holosen DAS Kali Baksoko, Pacitan (sumber: Dokumen Balai Arkeologi DIY, 2019).

\section{SIMPULAN}

Dapat disimpulkan bahwa Budaya Pacitanian diyakini sebagai budaya yang berlangsung pada Kala Plestosen, dicirikan dengan pengembangan teknologi paleolitik di sepanjang Kali Oyo, Gunungkidul sampai Kali Baksoko, Pacitan. Pertanggalan absolut dan sejarah kronologi geologisnya masih menjadi perdebatan, namun kecenderungan sebagai budaya yang berlangsung Kala Plestosen terlihat kuat. Kondisi alam glasial-interglasial Kala Plestosen sangat berpengaruh pada pola hidup manusia yang masih bergantung dengan ketersediaan lingkungan alam atas kebutuhan makanan dan bahan baku untuk pembuatan peralatan sehari-hari. Data fauna dan hominid merupakan data utama dalam merekonstruksi perubahan alam tersebut. Kawasan Gunung Sewu minim data tersebut, namun tinggalan budaya berlimpah. Hal tersebut berbanding terbalik dengan temuan di situs Sangiran dan situs-situs Plestosen lainnya yang cenderung melimpah temuan fosil fauna dan hominid. Menjadi pertanyaan apakah Kala Plestosen, Kawasan Gunung Sewu merupakan tempat memproduksi alat-alat paleolitik, di mana kawasan DAS Bengawan Solo merupakan areal perburuan. Di lain pihak beberapa situs hunian gua (Song Terus) mengindikasi dihuni Kala Plestosen dengan berbagai temuan Pacitanian yang selama ini berlangsung di areal terbuka sepanjang sungai purba. 
Perubahan budaya dan alam Kala Holosen yang kondisi alamnya seperti sekarang ini, di Kawasan Gunung Sewu sangat potensial baik temuan artefak, fauna maupun rangka manusia pendukungnya, yaitu Homo sapiens. Perubahan alam dengan fauna yang menjadi buruan manusia penghuni gua menunjukkan jenis fauna yang berbeda dengan jenis fauna yang hidup Kala Plestosen. Kecenderungan tidak mampu bertahan hidup dengan perubahan iklim dan hutan menjadikan fauna-fauna yang hidup Kala Plestosen punah. Hal tersebut berdampak pada perubahan genus Homo juga dari "punahnya" Homo erectus digantikan dengan munculnya Homo sapiens. Selain itu, peralatan sebagai tinggalan budaya yang digunakan pun juga mengalami perubahan yang signifikan, yaitu dari teknologi paleolitik ke pengembangan teknologi mesolitik dan neolitik. Hal tersebut terkait dengan jenis fauna buruan manusia yang juga berubah. Pola huniannya pun mengalami perubahan dari mengembara ke hidup menetap di gua atau ceruk.

\section{DAFTAR PUSTAKA}

Anderson, D. D. (1997). Cave archaeology in Southeast Asia. Geoarchaeology, 12(6), 607-638. https://doi.org/10.1002/(SICI)1520-6548(199709)12:6<607::AIDGEA5>3.0.CO;2-2

Bemmelen, R. Van. (1949). Geology of Indonesia Vol-IA General.pdf.

Bergh, G. D. Van Den, Vos, J. De, Sondaar, P. Y., \& Aziz, F. (1996). Pleistocene Zoogeographic Evolution Of Java (Indonesia) And Glacio-Eustatic Sea Level Fluctuations: A Background For The Presence Of Homo. Bulletin of Indo-Pacific Prehistory Association, 16(Chiang May Papers Volume 1), 7-21.

Crabtree, D. E. (1972). An Introduction to Flintworking. Idaho State University.

Crumley, C., \& Marquardt, W. (1990). Landscape : A Unifying Concept in Regional Analysis. In K. M. S. Allen, S. W. Green, \& E. B. W. Zubrow (Eds.), Interpreting Space: GIS and Archaeology (Issue January, pp. 73-79). Taylor \& Francis.

Haryadi, H. (1995). Kemungkinan Penerapan Sistem Seting dalam Penemukenalan Penataan Ruang Kawasan. Berkala Arkeologi Edisi Khusus, XV(Manusia dalam Ruang), 5-9.

Heekeren van, H. (1957). The Stone Age of Indonesia. In The Stone Age of Indonesia. Verhandelingen van het Koninklijk Instituut voor Taal-, Land- en Volkenkunde. https://doi.org/10.26530/OAPEN_613384

Hill, A., Rosas, A., Hublin, J.-J., Kimbel, W., Leakey, M., Manzi, G., Pilbeam, D., Roche, H., Smith, F., Smith, R., Stringer, C., Thackeray, F., Weiss, M., \& Zegura, S. (2011). Encyclopedia of Human Evolution (B. Wood (ed.); Volume 1). Blackwell Publishing.

Mahareni, E. (2002). Late Pleistocene Vertebrates in Gunung Sewu. In T. Simanjuntak (Ed.), Gunung Sewu in Prehistoric Times (pp. 133-144). Gadjah Mada University Press.

Morwood, M. J., Sutikna, T., Saptomo, E. W., Westaway, K. E., Turney, C. S. M., Fifield, K., Allen, H., \& Soejono, R. P. (2008). Climate, people and faunal succession on Java, Indonesia : evidence from Song Gupuh. 35, 1776-1789. https://doi.org/10.1016/j.jas.2007.11.025

Registrasi, S. K. K. P. dan. (2011). Laporan Kegiatan Verifikasi Cagar Budaya di 
Kabupaten Pacitan.

Sémah, A.-M., Setiagama, K., Sémah, F., Détroit, F., Grimaud-Hervé, D., \& Hertler, C. (2007). First Islanders. Human Origins Patrimony in Southeast Asia.

Semenanjung - HOPsea.

Sémah, A., \& Sémah, F. (2012). The rain forest in Java through the Quaternary and its relationships with humans (adaptation, exploitation and impact on the forest).

Quaternary International, 249, 120-128. https://doi.org/10.1016/j.quaint.2011.06.013

Sémah, F., Sémah, A., \& Simanjuntak, T. (2003). More than a million years of human occupation in insular Southeast Asia: the early archaeology of eastern and central Java. In J. Mercader (Ed.), Under the Canopy: The Archaeology of Tropical Rain Forests (pp. 161-190). Rutgers University Press.

Semah, O. I. S., Semah, A., \& Falgueres, C. (2004). The significance of the Punung karstic area (Eastern Java) for the chronology of the Javanese Palaeolithic, with special reference to the Song Terus cave 4. The significance of the Punung karstic area ( eastern Java) for the chronology of the Javanes. January.

Simanjuntak, H. T., Handini, R., \& Prasetyo, B. (2004). Prasejarah Gunung Sewu. Ikatan Ahli Arkeologi Indonesia. https://books.google.co.id/books?id=0KT9swEACAAJ

Simanjuntak, H. T., \& Widianto, H. (2012). Prasejarah. In A. Taufik (Ed.), Indonesia Arus Sejarah Jilid 1. PT Ichtiar Baru van Hoeve.

Simanjuntak, T. (2004). New Insight on the Prehistoric Chronology of Gunung Sewu, Java, Indonesia. In S. G. Keates \& J. M. Pasveer (Eds.), Modern Quaternary Research Southeast Asia: Quaternary Research In Indonesia (pp. 9-30). A.A. Belkema.

Simanjuntak, T. (2006). Indonesia-Southeast Asia: Climates, settlements, and cultures in Late Pleistocene. Comptes Rendus Palevol, 5(1-2), 371-379. https://doi.org/10.1016/j.crpv.2005.10.005

Simanjuntak, T., \& Prasetyo, B. (2002). Subsistence of the Cave Dwellers. In T. Simanjuntak (Ed.), Gunung Sewu in Prehistoric Times (pp. 147-164). Gadjah Mada University Press.

Simanjuntak, T., Sémah, F., \& Gaillard, C. (2010). The palaeolithic in Indonesia: Nature and chronology. Quaternary International, 223-224, 418-421. https://doi.org/10.1016/j.quaint.2009.07.022

Soejono, R. (1976). Tinjauan tentang Pengkerangkaan Prasejarah Indonesia. In Aspekaspek Arkeologi Indonesia (Vol. 5). Proyek PELITA, Pembinaan Kepurbakalaan dan Peninggalan Nasional.

Sondaar, P. Y. (1984). Faunal evolution and the mammalian biostratigraphy of Java. Cour. Forsch. Inst. Senckenberg, 69, 219-235.

Storm, P. (2001). The evolution of humans in Australasia from an environmental perspective. 171, 363-383.

Storm, P., Aziz, F., Vos, J. De, Kosasih, D., Baskoro, S., \& Hoek, L. W. Van Den. (2005). Late Pleistocene Homo sapiens in a tropical rainforest fauna in East Java. 2005(April 1938), 536-545. https://doi.org/10.1016/j.jhevol.2005.06.003

Tanudirjo, D. A. (2017). Arkeologi Lanskap (EHPA Intern Balar Yogyakarta).

van der Kaars, W. A., \& Dam, M. A. C. (1995). A 135,000-year record of vegetational and climatic change from the Bandung area, West-Java, Indonesia.

Palaeogeography, Palaeoclimatology, Palaeoecology, 117(1-2), 55-72. 
https://doi.org/10.1016/0031-0182(94)00121-N

Westaway, K. E., Morwood, M. J., Roberts, R. G., Rokus, A. D., Zhao, J. x., Storm, P., Aziz, F., van den Bergh, G., Hadi, P., Jatmiko, \& de Vos, J. (2007). Age and biostratigraphic significance of the Punung Rainforest Fauna, East Java, Indonesia, and implications for Pongo and Homo. Journal of Human Evolution, 53(6), 709717. https://doi.org/10.1016/j.jhevol.2007.06.002

Westaway, K. E., Zhao, J., Roberts, R. G., Chivas, A. R., Morwood, M. J., \& Sutikna, T. (2007). Initial speleothem results from western Flores and eastern Java, Indonesia: were climate changes from 47 to $5 \mathrm{ka}$ responsible for the extinction of Homo floresiensis? Journal of Quaternary Science, 22(5), 429-438. https://doi.org/10.1002/jqs.1122

Whitten, T., Soeriaatmadja, R. E., \& Afiff, S. A. (1996). The Ecology of Java and Bali. In The Ecology of Indonesia Series (Vol. 2). Periplus Editions.

\section{HASIL DISKUSI}

\section{Pertanyaan}

1. Ary Sulistyo (TACB Kota Depok)

Nilai Apa yang didapat dari hasil penelitian lingkungan yang telah dilakukan tersebut?

2. Restu A Rahayuningsih

Disebutkan bahwa fauna Kala Pleistosen tidak mampu bertahan hidup dengan perubahan lingkungan dan iklim atau punah. Apa itu berlaku untuk semua spesies? Adakah keberlanjutan genetik fauna-fauna kala Pleistosen ke fauna kala Holosen? Apakah kepunahan fauna juga berkaitan dengan pola hidup manusia pendukungnya?

\section{Jawaban}

1. Pengetahuan tentang perlunya menjaga lingkungan agar tidak rusak. Data lingkungan masa lampau harus menjadi pelajaran dan peringatan di masa yang akan datang. Penelitian tentang perubahan alam dari kala Plestosen yang masih terjadi glasial dan interglasial yang dibuktikan pada biostratigrafi (alam/lapisan tanah dan fauna/makhluk hidup) ke Kala Holosen akan memperkaya ilmu terutama tentang paleoekologi, pola hidup serta evolusi manusia dan perubahan budaya.

2. Tidak semuanya punah, karena evolusi berlangsung lambat. Jadi masih ada beberapa spesies yang berlanjut di masa selanjutnya. Terjadinya peningkatan suhu yang mencapai titik maksimum pada sekitar 8.500 BP, menyebabkan beberapa species tidak mampu bertahan hidup (punah) antara lain species Stegodhon dan Kerbau purba. Pada saat itu, hutan hujan mencapai titik perkembangannya yang tertinggi. Hal tersebut, menyebabkan jenis binatang tertentu yang mampu bertahan hidup, antara lain jenis Rusa, Kijang, Babi, dan Monyet. Selain itu kondisi tersebut merubah pola hidup dari mengembara ke semi menetap di gua atau ceruk dengan ketersediaan jenis binatang buruan yang 
lebih kecil dan diikuti perubahan pengembangan teknologi alat batu dari paleolitik ke mesolitik.

Jenis fauna yang masih bertahan hidup, punah, dan munculnya beberapa fauna baru pada Kala Plestosen (fauna Ngandong) ke Kala Holosen (fauna Punung), penyebabnya adanya perubahan iklim dan suhu (Sondaar, 1984).

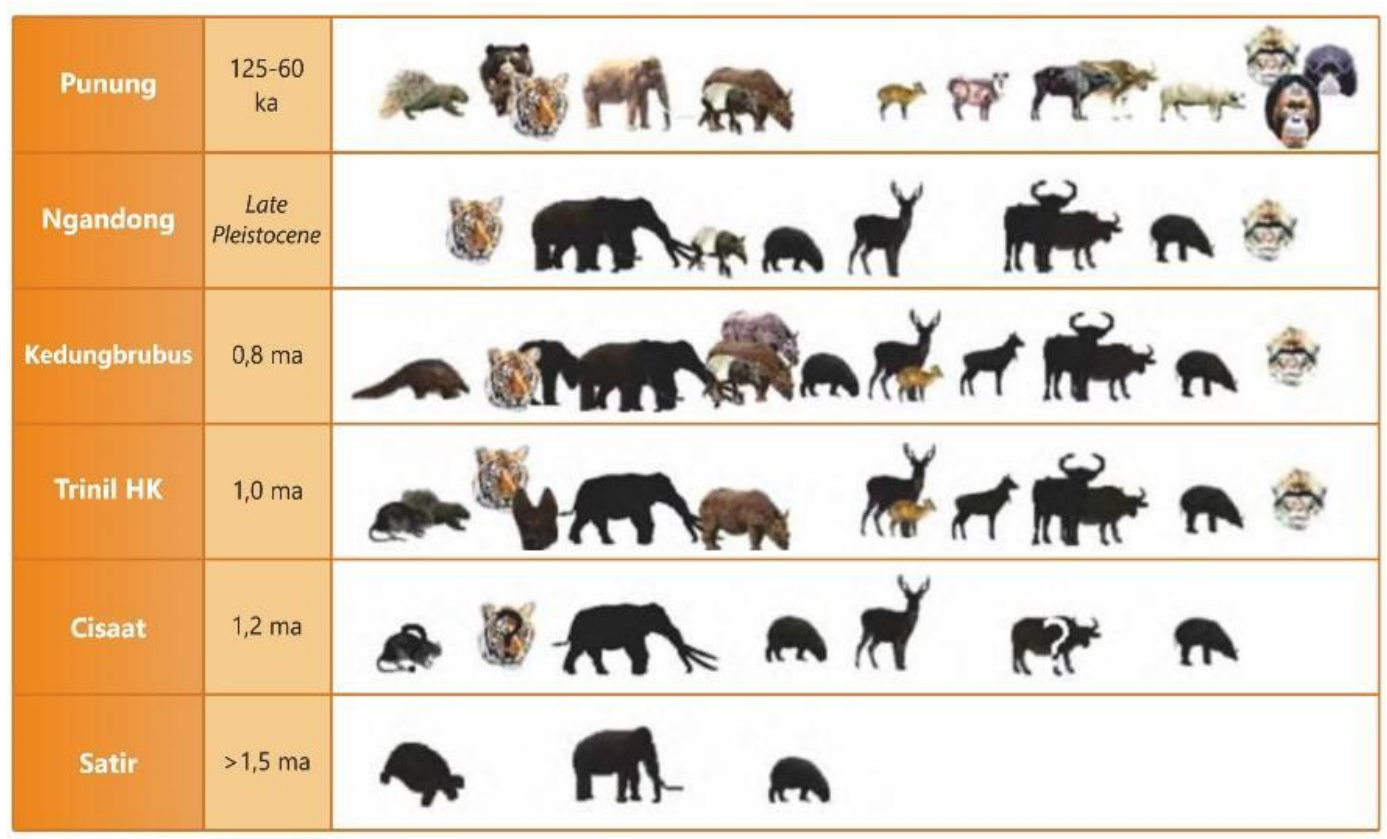

Keterangan: ka: kilo (ribuan tahun yang lalu), ma: million (jutaan tahun yang lalu)

72 